\title{
Sepsis-induced acute kidney injury: kidney protection effects by antioxidants
}

\author{
Lesão renal aguda induzida pela sepse: efeito de proteção renal dos antioxidantes \\ Lesión renal aguda inducida por sepsis: efecto de protección renal de los antioxidantes
}

\begin{abstract}
Carolina Ferreira Vasco', Mirian Watanabe', Cassiane Dezoti da Fonseca', Maria de Fátima Fernandes Vattimo'
'Universidade de São Paulo, School of Nursing. São Paulo, Brazil.
\end{abstract}

How to cite this article:

Vasco CF, Watanabe M, Fonseca CD, Vattimo MFF. Sepsis-induced acute kidney injury: kidney protection effects by antioxidants. Rev. Bras. Enferm. [Internet]. 2018;71(4):1921-7. DOI: http://dx.doi.org/10.1590/0034-7167-2017-0469

Submission: 06-25-2017 Approval: 08-23-2017

\section{ABSTRACT}

Objective: To evaluate the antioxidant action of $\mathrm{N}$-acetylcysteine and diosmin-hesperidin in an experimental model of sepsisinduced acute kidney injury in rats. Methods: The study used 20 Wistar adult male rats divided into the following groups: control (laparotomy with no induction of abdominal sepsis), sepsis (experimental model of sepsis with cecal ligation and puncture), $\mathrm{N}$-acetylcysteine + sepsis and diosmin-hesperidin + sepsis. The evaluation contemplated physiological parameters (temperature, glycemia, and average blood pressure), kidney function (creatinine clearance), oxidative stress (urinary peroxides) and kidney histology. Results: The animals submitted to cecal ligation and puncture (sepsis) presented lower body temperature, lower average blood pressure, reduced creatinine clearance and increased urinary hydrogen peroxide levels. Treatment with diosmin-hesperidin improved kidney function and led to a reduction in the excretion of oxidative metabolites. Conclusion: The present study highlighted the protective antioxidant action of diosmin-hesperidin in the experimental model of sepsis-induced acute kidney injury.

Descriptors: Acute Kidney Injury; Sepsis; Diosmin; Hesperidin; Oxidative Stress.

\section{RESUMO}

Objetivo: Avaliar a ação antioxidante de agentes como a $\mathrm{N}$-acetilcisteína e diosmina-hesperidina em modelo experimental de lesão renal aguda induzida pela sepse em ratos. Método: Foram utilizados vinte ratos Wistar, adultos e machos, divididos nos seguintes grupos: Controle (laparotomia sem indução de sepse abdominal), Sepse (modelo experimental de sepse com ligadura e punção do cécum- LPC), N-acetilcisteína + Sepse e Diosmina Hesperidina+Sepse. Foram avaliados parâmetros fisiológicos (temperatura, glicemia e pressão arterial média), função renal (clearance de creatinina), estresse oxidativo (peróxidos urinários) e histologia renal. Resultados: Os animais submetidos à LPC (sepse) apresentaram redução da temperatura corporal, da pressão arterial média, do clearance de creatinina e elevação nos níveis de peróxidos de hidrogênio urinários. O tratamento com a Diosmina-Hesperidina melhorou a função renal com redução na excreção dos metabólitos oxidativos. Conclusão: Este estudo destacou a ação renoprotetora antioxidante da Diosmina-Hesperidina no modelo experimental de lesão renal aguda induzida pela sepse.

Descritores: Lesão Renal Aguda; Sepse; Diosmina; Hesperidina; Estresse Oxidativo.

\section{RESUMEN}

Objetivo: Evaluar la acción antioxidante de agentes como la N-acetilcisteína y Diosmina-Hesperidina en modelo experimental de lesión renal aguda inducida por sepsis en ratones. Método: Fueron utilizados veinte ratones Wistar, adultos y machos, divididos en los grupos: Control (laparotomía sin inducción de sepsis abdominal), Sepsis (modelo experimental de sepsis con ligadura y punción de ciego-LPC), N-acelsisteína + Sepsis y Diosmina Hesperidina + Sepsis. Se evaluaron parámetros fisiológicos (temperatura, glucemia y presión arterial promedio), la función renal (clearance de creatinina), el estrés oxidativo (peróxidos urinarios) e histología renal. Resultados: Los animales sometidos a LPC (sepsis) presentaron reducción de la temperatura corporal, de la presión arterial promedio, del clearance de creatinina e incremento de niveles de peróxidos de hidrógeno urinarios. El tratamiento con Diosmina-Hesperidina mejoró la función renal, reduciendo la excreción de metabolitos oxidativos. Conclusión: Este estudio destacó la acción renoprotectora antioxidante de la Diosmina-Hesperidina en el modelo experimental de lesión renal aguda inducida por sepsis.

Descriptores: Lesión Renal Aguda; Sepsis; Diosmina; Hesperidina; Estrés Oxidativo. 


\section{INTRODUCTION}

Acute kidney injury (AKI) is one of the most frequent and severe physiopathological disorders in hospitalized patients, of whom $20 \%$ to $40 \%$ are in intensive care units (ICUs) ${ }^{(1)}$. According to the Kidney Disease: Improving Global Outcomes (KDIGO) guidelines, an acute kidney injury is clinically characterized by an increase equal or superior to $0.3 \mathrm{mg} / \mathrm{dL}$ in serum creatinine in a 48-hour period or a 1.5 -fold increase in comparison with its basal level, known or preestablished, or a urinary flux inferior to $0.5 \mathrm{~mL} / \mathrm{kg}$.h during six hours ${ }^{(2)}$. There are many causes which lead to this dysfunction, and sepsis is one of the main factors involved in the development of the condition ${ }^{(3-4)}$.

Sepsis is a serious clinical issue defined as an intense systemic inflammatory response provoked by the interaction between microbial antigens and components from the innate immune system. Activation of inflammation and coagulation pathways is the main cause of circulatory failure and dysfunction of multiple organs observed in sepsis ${ }^{(5)}$.

Many studies have demonstrated the association between AKI and sepsis. An investigation which examined 3,147 critically ill patients reported that around $37 \%$ of them developed sepsis; AKI was diagnosed in $51 \%$ of the cases and associated with $41 \%$ of mortality rates in ICUs(6). Another recent clinical trial that used vasopressin or norepinephrine as a primary treatment for sepsis showed that AKI occurred in $45 \%$ of the patients and nearly $30 \%$ needed kidney replacement therapy $y^{(7)}$.

The unfavorable epidemiology of sepsis-induced AKI, the need to systematize care and the urgency to treat these patients make it necessary for the scientific community to design care protocols and point up new therapeutic alternatives.

Despite the significant number of publications related to sepsis, the physiopathological mechanisms involved in the process and the main systemic mediators activated during the event are not clear yet. It is known that hemodynamic fluctuations such as hypotension and reduced renal blood flow can induce renal ischemia and tissue hypoxia, which leads to a decreased glomerular filtration rate ${ }^{(4)}$. Concurrently, the expression of reactive oxygen species (ROS) impacts the cell signaling cascade, which causes deleterious effects on kidney endothelial and epithelial cells such as oxidative injury, characterized by lipid peroxidation in cell membrane, protein oxidation and DNA damage ${ }^{(4,8)}$. These mechanisms suggest that the oxidation of cell membranes leading to cell death can be the main physiopathological process involved in sepsis-induced AKI.

Many substances with antioxidant properties are under investigation and have been incorporated into clinical practice in an attempt to prevent sepsis-induced AKI. $\mathrm{N}$-acetylcysteine and the combination of diosmin and hesperidin stand out in this scenario for providing antioxidant renoprotective action through the scavenging of ROS and the induction of endogenous antioxidant enzymes, such as catalase and glutathione peroxidase $\mathrm{e}^{(9-10)}$.

Although there are many publications addressing clinical and experimental sepsis, results showing the characteristics of application in the treatment of this syndrome are restricted.

Taking into account that oxidative stress seems to feature sepsis-induced AKI physiopathology and that the identification of drugs which may have a positive effect on the disease represents therapeutic possibilities to protect kidney cells and contribute to decrease mortality rates and improve the prognosis of patients with sepsis, the present study aimed to evaluate the effect of sepsis on the kidney function of rats and examine if drugs which are not commonly used for this purpose but that have a proven antioxidant effect can have renoprotective properties ${ }^{(8)}$.

Experimental research allows to isolate the biological variables specifically involved in the physiopathology of kidney injury and comes through a practical, objective and accurate model whose results can ground the knowledge necessary for the development of a safe practice. Nurses play a key role in the early identification of the main signs and symptoms of sepsis in clinical practice. A better understanding of the pathology, together with the dissemination of new therapeutic proposals to combat sepsis and $\mathrm{AKI}$, favor professional improvement and consolidate the idea of nurses as reference collaborators to achieve high-quality care.

\section{OBJECTIVE}

To evaluate the antioxidant renoprotective action of $\mathrm{N}$ acetylcysteine and diosmin-hesperidin in a sepsis-induced AKI experimental model.

\section{METHOD}

\section{Ethical aspects}

The procedures necessary for the development of the present study are in agreement with the ethical principles adopted by the Brazilian School for Animal Testing and were approved by the Animal Research Ethics Committee from the Medical School at the University of São Paulo, as per protocol 378/13, to carry out tests with animals.

\section{Study design, setting and period}

Quantitative and experimental study with an animal model performed in the Experimental Laboratory for Animal Models of the School of Nursing at the University of São Paulo from May to December 2015.

\section{Sample}

The experiments were executed with 20 adult male Wistar rats, with weights ranging from 250 to 300 grams. The animals were kept in collective cages, with free access to water and food, appropriate thermal conditions (temperature of $24^{\circ} \mathrm{C}$ ) and alternate day-night cycles. The dark cycle in the experimental animal facility was set to last approximately ten hours.

\section{Study protocol}

The animals were divided into the following groups: Control: the rats were anesthetized with an injection of $50 \mathrm{mg} / \mathrm{kg}$ of intraperitoneal sodium thiopental and submitted to laparotomy for cecum manipulation with no puncture.; Sepsis: The rats were anesthetized with an injection of $50 \mathrm{mg} / \mathrm{kg}$ of intraperitoneal sodium thiopental and submitted to laparotomy and cecal ligation and puncture (CLP) ${ }^{(11)}$. The procedure involved a single puncture in the cecum with a $40 \mathrm{x}$ $12 \mathrm{~mm}$ needle. After the operation, the animals stayed in heated 
collective cages for twelve hours, with no blood and fluid replacement other than the ad libitum; N-acetylcysteine (NAC) + sepsis: the animals received NAC (Zambon-Brazil) at the dose of 150 $\mathrm{mg} / \mathrm{kg}$, through gavage, thirty minutes before the CLP procedure; Diosmin-hesperidin $(\mathrm{DH})+$ sepsis: the animals received DH (Aché Laboratório-Brazil), at the dose of $13 \mathrm{mg} / \mathrm{kg}$, through gavage, thirty minutes before the CLP procedure.

Metabolic cage: after the execution of the protocol, the animals were placed in individual metabolic cages for collection of urine after 24 hours to evaluate kidney function and oxidative metabolites.

Physiological parameters: at the end of the 24-hour period, the animals were anesthetized with an injection of $50 \mathrm{mg} / \mathrm{kg}$ of intraperitoneal sodium thiopental to assess the rectal temperature with the clinical thermometer Premium Oval ${ }^{\circledR}$ with mercury and the average blood pressure through the puncture of the abdominal aorta with a Scalp $21{ }^{\circledR}$ connected to a Dixtal ${ }^{\circledR}$ pressure transducer multiparameter monitoring device. A blood sample was collected for evaluation of capillary glycemia with the Accu-Chek Active ${ }^{\circledR}$ system.

Whole blood sampling: collection of terminal blood was carried out via puncture of abdominal aorta for posterior evaluation of kidney function.

Kidney function: this parameter was assessed through creatinine clearance. The colorimetric method based on Jaffe's reaction was used to quantify the values of serum and urine creatinine. Creatinine clearance was calculated by the following formula: creatinine clearance $=$ urine creatinine $\times 24$-hour urine flux/serum creatinine ${ }^{(12)}$.

Urinary peroxides: evaluation of urinary peroxides was executed through the FOX-2 method, the use of iron - xylenol orange, which oxidizes the $\mathrm{Fe}^{2+}$ cation and thus produces a blue-purplish complex $\left(\alpha=4.3 \times 10^{4} \mathrm{M}^{-1} \mathrm{~cm}^{-1}\right)^{(12-13)}$.

Kidney histology: the left kidney was removed and prepared for histological cutting. Kidney tissues were colored with hematoxylin-eosin and periodic acid-Schiff (PAS). Histopathological alterations were analyzed by a renal pathologist blindly.
Histological lesions, such as loss of microvilli in proximal tubules, tubular cell swelling, inflammation, necrosis and tubular regeneration, ischemic glomeruli, congestion and amorphous corticomedullary were qualitatively graded as mild $(+)$, moderate $(++)$, or severe $(+++)^{(14)}$.

\section{Analysis of results and statistics}

Results were presented in the mean \pm standard deviation format. Data were submitted to analysis of variance (ANOVA) and Tukey's test to compare the groups. The level of significance used in the present study was $p<0.05$.

\section{RESULTS}

Table 1 shows that animals with sepsis-induced by CLP presented a reduction of rectal temperature and average arterial pressure in comparison with the control group ( $p<0.05$ ). Treatment with diosmin-hesperidin resulted in an increase in both parameters when the results were compared to those of the sepsis group $(p<0.05)$. The sepsis and $\mathrm{DH}+$ sepsis groups had increased glycemia in comparison with the control group $(p<0.05)$. In addition, the animals in the sepsis group had a lower urinary flux in comparison with those in the control group $(\mathrm{p}<0.05)$.

Table 2 shows that, if urinary creatinine is analyzed separately, the sepsis and NAC + sepsis groups presented a significant reduction in the parameter in comparison with the control group, while the serum creatinine in the $\mathrm{DH}+$ sepsis group increased when compared to the results of these two groups (Sepsis and NAC + sepsis) ( $p<0.05)$. Creatinine clearance in the sepsis and NAC + sepsis groups was significantly higher than that in the control group ( $p<0.05$ ). Treatment with $\mathrm{DH}$ was associated with an improvement in the kidney function, as shown by the comparison with the sepsis and NAC + sepsis groups, but a poorer kidney function than that exhibited by the animals from the control group ( $p<0.05)$.

Table 1 - Physiological parameters, São Paulo, Brazil, 2017

\begin{tabular}{|c|c|c|c|c|}
\hline Groups (n) & $\begin{array}{l}\text { Rectal temperature } \\
\left({ }^{\circ} \mathrm{C}\right)\end{array}$ & $\underset{(\mathrm{mmHg})}{\mathrm{AAP}}$ & $\begin{array}{c}\text { Capillary glycemia } \\
\text { (mg/dL) }\end{array}$ & $\begin{array}{l}\text { Urinary volume } \\
(\mathrm{mL} / \mathrm{min})\end{array}$ \\
\hline Control (5) & $36.1 \pm 0.34$ & $85.8 \pm 5.89$ & $114.2 \pm 50.1$ & $0.067 \pm 0.001$ \\
\hline Sepsis (5) & $34.2 \pm 0.32^{\mathrm{a}}$ & $58.8 \pm 5.60^{a}$ & $232.0 \pm 47.6^{a}$ & $0.010 \pm 0.006^{a}$ \\
\hline NAC + sepsis (5) & $35.8 \pm 0.32$ & $78.8 \pm 5.62$ & $194.4 \pm 47.8$ & $0.009 \pm 0.003^{a}$ \\
\hline $\mathrm{DH}+$ sepsis (5) & $36.0 \pm 0.10^{\mathrm{b}}$ & $92.0 \pm 0.60^{b}$ & $221.0 \pm 51.0^{\mathrm{a}}$ & $0.008 \pm 0.002^{\mathrm{a}}$ \\
\hline
\end{tabular}

Note: ${ }^{a} p<0.05$ versus control; ${ }^{b} p<0.05$ versus sepsis. AAP - average arterial pressure, $N A C-N$-acetylcysteine, $D H$-diosmin-hesperidin.

Table 2 - Kidney function and oxidative stress, São Paulo, Brazil, 2017

\begin{tabular}{lcccc}
\hline \multicolumn{1}{c}{ Groups $(\mathbf{n})$} & $\begin{array}{c}\text { Urinary creatinine } \\
(\mathbf{m g} / \mathbf{d L})\end{array}$ & $\begin{array}{c}\text { Serum creatinine } \\
(\mathbf{m g} / \mathbf{d L})\end{array}$ & $\begin{array}{c}\text { Creatinine } \\
\text { clearance/100 } \mathbf{g}(\mathbf{m L} / \mathbf{m i n})\end{array}$ & $\begin{array}{c}\text { Urinary peroxides } \\
(\mathbf{n m o l} / \mathbf{m g} \mathbf{~ c r e a t i n i n e )}\end{array}$ \\
\hline Control (5) & $104.9 \pm 8.3$ & $0.49 \pm 0.19$ & $0.64 \pm 0.05$ & $2.1 \pm 2.2$ \\
Sepsis (5) & $41.3 \pm 7.8^{\mathrm{a}}$ & $0.74 \pm 0.18$ & $0.20 \pm 0.04^{\mathrm{a}}$ & $12.4 \pm 2.1^{\mathrm{a}}$ \\
NAC+sepsis (5) & $38.1 \pm 7.9^{\mathrm{a}}$ & $0.69 \pm 0.18$ & $0.18 \pm 0.04^{\mathrm{a}}$ & $11.4 \pm 2.1^{\mathrm{a}}$ \\
DH+ sepsis (5) & $94.0 \pm 8.0^{\mathrm{bc}}$ & $0.80 \pm 0.11^{\mathrm{a}}$ & $0.49 \pm 0.05^{\mathrm{abc}}$ & $3.4 \pm 1.1^{\mathrm{bc}}$ \\
\hline
\end{tabular}

Note: ${ }^{a} p<0.001$ versus control, ${ }^{b} p<0.001$ versus sepsis, ${ }^{c} p<0.001$ versus $N A C+$ sepsis; NAC - N-acetylcysteine. 
The rats from the sepsis and NAC + sepsis groups presented high levels of urinary hydrogen peroxides in comparison with the control group $(p<0.001)$. The administration of diosminhesperidin caused a significant decrease in the results of this parameter $(p<0.05)$.

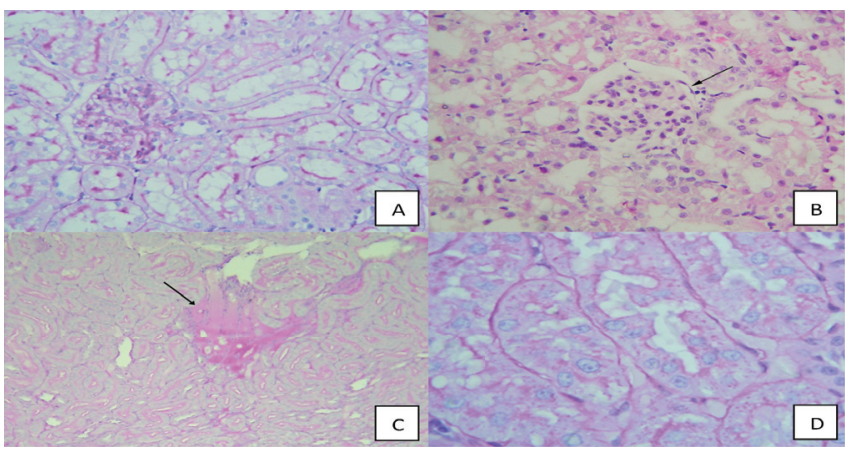

Figure 1 - Renal histology of the studied groups: control (A), sepsis (B), NAC + sepsis (C) and DH + sepsis (D) - São Paulo, Brazil, 2017 (magnification of 400x)

Figure 1 displays a histological section of each group. The renal histology of the control group $(\mathrm{A})$ is intact, with no alterations in basal membranes and in the microvilli of proximal tubular cells. The histology of the other groups (sepsis (B), NAC + sepsis (C) and $\mathrm{DH}+$ sepsis (D)) revealed similar structural alterations, with loss of microvilli in proximal tubules, tubular cell swelling, ischemic glomeruli, congestion and amorphous corticomedullary.

Table 3 exhibits the qualitative analysis of histopathological changes in the four groups. The lesions were classified as mild $(+)$, moderate $(++)$, or severe $(+++)$.

Table 3 - Classification of histopathological changes in the four studied groups, São Paulo, Brazil, 2017

\section{Histopathological alterations}

\section{Control Sepsis}

\section{Groups (n)}

$\mathrm{NAC}+$ sepsis $\mathrm{DH}+$ sepsis

(5)

Loss of microvilli in proximal tubules

Tubular cell swelling

Inflammation, necrosis and tubular regeneration

Ischemic glomeruli

Congestion

Amorphous corticomedullary

$+$

(5)

$\begin{array}{ccc}+ & + & + \\ +++ & +++ & +++ \\ - & - & - \\ ++ & + & + \\ +++ & ++ & ++ \\ + & +++ & ++\end{array}$

The present study, designed to evaluate the antioxidant action of $\mathrm{N}$-acetylcysteine and diosmin-hesperidin in sepsis-induced $\mathrm{AKI}$, confirmed that the experimental sepsis model has similar characteristics to those expressed in humans, resulting from trauma with perforation of intestinal loops, colitis or post-surgical peritonitis ${ }^{(14)}$. Characteristic symptoms of sepsis were observed, such as hypothermia, reduction of the average arterial pressure to values inferior to $60 \mathrm{mmHg}$, and hyperglycemia ${ }^{(4-5)}$, reasserting the accuracy of the CLP technique in the experimental model.

The decreased creatinine clearance and increased urinary peroxide levels revealed the presence of AKI following sepsis, probably triggered by an oxidation mechanism. The treatment with diosmin-hesperidin exhibited a significant antioxidant effect in this model of kidney injury.

The pathogenesis of this dysfunction, secondary to endotoxemia, derives from the pro-inflammatory response, including secretion of cytokines and ROS. In this situation, there are hemodynamic alterations in the kidney microcirculation, with the predominance of vasoconstrictor mediators that result in tissue hypoxia and renal ischemia. The renal hypoperfusion settled in these cases is a consequence of a reduced blood flow to the kidney and tubular lesions provoked by inflammatory cytokines ${ }^{(8,15)}$. In the present study, there was a decrease in the average arterial pressure in animals in which sepsis was induced, similar to what is observed in clinical practice ${ }^{(5,7)}$. This is considered a characteristic sign of the syndrome and must be identified early for the medical team to plan a quick and effective care strategy. Body temperature is another sign of sepsis. Hyperthermia, hypothermia and the association of these conditions are expected in the clinical picture of sepsis ${ }^{(16-17)}$. In the present investigation, hypothermia prevailed in the animals submitted to sepsis, and only the group treated with diosminhesperidin showed a reversal in this parameter. The deleterious effects of hypothermia in patients with sepsis are not clear yet, but some authors claim that low body temperature is a factor that impairs self-protection when an organism is facing the infectious process that characterizes sepsis ${ }^{(4,16,18)}$.

In addition, the data of the present study revealed high serum glycemia in all the rats submitted to sepsis, a result that validates the experimental model. Hyperglycemia is common in critically ill patients even when they do not have preexisting diabetes mellitus, which increases their morbidity and mortality

Five histological slides were analyzed in each group. Each slide was divided into six areas for qualitative evaluation of the lesions. The grades given to the areas were - (no lesion), + (mild lesion: $25 \%$ of the observed area), ++ (moderate lesion: $50 \%$ of the observed area), +++ (severe lesion: over $75 \%$ of the observed area).

\section{DISCUSSION}

The combination of sepsis and AKI is associated with the development of organ failure in ICU patients ${ }^{(1,4)}$. rates. This clinical condition is considered stress hyperglycemia, resulting from the release of counterregulatory hormones, for instance corticosteroids and catecholamines, and pro-inflammatory mediators. Stress hyperglycemia is diagnosed when the glycated hemoglobin level is higher than $6.5 \%$ or the glucose concentration is higher than $140 \mathrm{mg} / \mathrm{dL}$ in the absence of diabetes history ${ }^{(4,19-20)}$.

As for the kidney function, the present investigation showed a decrease in the animals' creatinine clearance associated with oliguria in animals with sepsis, which confirmed severe sepsis with AKI. The reduction in the glomerular filtration rate may 
have been triggered by the pressure difference in afferent and efferent arterioles in glomerular capillaries, which leads to a disproportionate increase in the vasodilation of afferent arterioles in comparison with the efferent ones. This phenomenon diminishes intraglomerular pressure and provokes a reduction in glomerular filtration, and consequently in purification of solutes $^{(8,15)}$. This mechanism is also observed in clinical sepsis and is fundamental for nurses to identify the condition, because the reduced urinary flux is considered a warning sign for sepsisinduced AKI. The other main signs and symptoms of the syndrome must also be monitored by healthcare professionals, so the care plan can be oriented to an intensive assistance, which demands a specialized multiprofessional team ${ }^{(21)}$.

The present study was designed to help elucidate the different routes involved in sepsis-induced AKI and highlighted the importance of oxidative stress through the analysis of urinary peroxides. The constant inflammatory response in sepsis results in the synthesis of cytokines and excessive production of nitric oxide, which induces severe hypotension, culminating with cell hypoxia through systemic vasodilation. Therefore, the continuity of the hypoxia state in kidney tubular cells favors the production of ROS, such as hydrogen peroxide $\left(\mathrm{H}_{2} \mathrm{O}_{2}\right)$ and the hydroxyl radical $\left(\mathrm{OH}^{-}\right)$, which are harmful to the renal parenchyma ${ }^{(8,13,22)}$. The measure of peroxide levels is considered a biomarker for the production of $\mathrm{H}_{2} \mathrm{O}_{2}$ and a predictive factor of the extension of oxidative stress in in vivo experimental models ${ }^{(22)}$. The increase in urinary hydrogen peroxide levels in the animals that were submitted to sepsis in the present investigation confirmed the presence of the oxidative lesion and emphasized it as a supporting element in the physiopathological mechanisms of sepsis.

In addition to the hemodynamic, functional and oxidative alterations described in the present study, histological analysis of the kidney tissue from the animals with sepsis revealed characteristics that corroborate structural alterations resulting from the clinical picture of sepsis, such as tubular lesions, corticomedullary congestion and ischemic glomeruli ${ }^{(4,8)}$.

The present investigation evaluated the action of two antioxidants, N-acetylcysteine and diosmin-hesperidin, in an attempt to identify new therapeutic alternatives to combat sepsis-induced AKI. $\mathrm{N}$-acetylcysteine has an unbound thiol group (-SH) in its structure, which interacts with free radicals $\left(\mathrm{OH}^{-}\right.$and $\left.\mathrm{H}_{2} \mathrm{O}_{2}\right)$ and enhances the production of glutathione peroxidase, the main antioxidant endogenous enzyme ${ }^{(8)}$. Despite these characteristics, the present study did not confirm the antioxidant effect of this substance in the reduction of urinary peroxide levels. This result may be associated with the severity of the lesion induced in the studied model. Although $\mathrm{N}$-acetylcysteine is frequently used in clinical protocols in the prophylaxis of contrast-induced nephropathy ${ }^{(23)}$, several publications have reported the absence of a renoprotective action in situations of AKIs associated with comorbidities, such as chronic kidney disease and diabetes mellitus ${ }^{(2425)}$. These findings assume that the reversal of cell and functional injuries induced by the sepsis models requires a more comprehensive antioxidant effect, which triggers other renoprotection pathways for the hemodynamic, physiological and oxidative alterations resulting from this syndrome.
In this scenario, the diosmin-hesperidin flavonoid showed more significant effects. The recovery shown in the average arterial pressure, creatinine clearance and body temperature, associated with a reduction in the release of hydrogen peroxides, suggests an anti-inflammatory and antioxidant action of this combination of drugs. Similar to the response observed in clinical settings ${ }^{(26)}$, the present study showed that diosminhesperidin induced an improvement of $77 \%$ in the kidney function of rats in sepsis. This outcome demonstrates that this treatment can be useful in the clinical practice in situations of risk of AKI in critically ill patients and may be included in protocols to prevent this complication.

Studies have shown that kidney damage in experimental models is potentially reversible or can be minimized the earlier the intervention takes place ${ }^{(27-28)}$. Wang et al. demonstrated that the antioxidant therapy can reverse the glomerular filtration rate and the renal blood flow in sepsis-induced $\mathrm{AKIs}^{(29)}$. Additionally, Santos et al. revealed that a preconditioning with statin for five days preserved the kidney function of animals submitted to sepsis through the CLP technique ${ }^{(30)}$. Another important flavonoid, resveratrol, exhibited a reduction effect on the activity of reactive nitrogen species, decreasing the redox imbalance in the sepsis experimental model ${ }^{(31)}$. Similarly, an improvement in the kidney function, with a reduction of oxidative metabolites, was observed in animals treated with diosmin-hesperidin and hesperidin in models of AKI induced by nephrotoxicity by amphotericin $\mathrm{B}^{(9,32-33)}$.

In conclusion, the present study evinced the antioxidant renoprotective action of diosmin-hesperidin in the experimental model of sepsis-induced AKI, demonstrated by the significant improvement in the kidney function and hemodynamics, physiological parameters and oxidative stress.

\section{Study limitation}

The present investigation was a preclinical study to elucidate the physiopathological mechanisms involved in sepsis-induced $\mathrm{AKI}$ and renoprotective drugs. Clinical trials are necessary to incorporate antioxidants such as diosmin-hesperidin into the care practice.

\section{Contributions to the nursing field}

The search for therapies which minimize renal damage in the presence of sepsis has been frequent in ICUs. Nurses, as members of a multidisciplinary healthcare team, have to assist patients in different situations, in a coordinate and continuous way, according to the ethical and bioethical principles of this profession. By knowing innovative treatments that promote better nursing care, they can help improve the quality of life of patients with sepsis.

\section{FUNDING}

The project from which the present paper originated was sponsored by the São Paulo Research Foundation through projects 2013/26560-2 and 2011/24028-6. 


\section{REFERENCES}

1. Case J, Khan S, Khalid R, Khan A. Epidemiology of acute kidney injury in the intensive care unit. Crit Care Res Pract [Internet]. 2013 [cited 2017 May 02];2013:479730. Available from: https://www.ncbi.nlm.nih.gov/pmc/articles/PMC3618922/pdf/CCRP2013-479730.pdf

2. Kidney Disease Improving Global Outcomes-KDIGO Acute Kidney Injury Work Group. KDIGO Clinical Practice Guidelines for Acute Kidney Injury. Kidney Int Suppl [Internet]. 2012 [cited 2017 May 02];2(Suppl1):1-138. Available from: http://www.kdigo. org/clinical practice guidelines/pdf/KDIGO $\% 20 \mathrm{AKI} \% 20 \mathrm{Guideline.pdf}$

3. Lameire NH, Bagga A, Cruz D, De Maeseneer J, Endre Z, Kellum JA, et al. Acute kidney injury: an increasing global concern. Lancet [Internet]. 2013[cited 2017 May 02];382:170-9. Available from: http://www.thelancet.com/pdfs/journals/lancet/PIIS01406736(13)60647-9.pdf

4. Bellomo R, Kellum JA, Ronco C, Wald R, Martensson J, Maiden M, et al. Acute kidney injury in sepsis. Intensive Care Med [Internet]. 2017 [cited 2017 May 02];43(6):816-28. Available from: https://link.springer.com/article/10.1007\%2Fs00134-017-4755-7

5. Singer M, Deutschman CS, Seymour CW, Shankar-Hari M, Annane D, Bauer M, et al. The third international consensus definitions for sepsis and septic shock (Sepsis-3). JAMA [Internet]. 2016 [cited 2017 May 02];315(8):801-10. Available from: http://jamanetwork. com/journals/jama/fullarticle/2492881

6. Poukkanen M, Vaara ST, Pettilä V, Kaukonen KM, Korhonen AM, Hovilehto S, et al. Acute kidney injury in patients with severe sepsis in Finnish Intensive Care Units. Acta Anaesthesiol Scand [Internet]. 2013 [cited 2017 May 02];57(7):863-72. Available from: http://onlinelibrary.wiley.com/doi/10.1111/aas.12133/epdf

7. Gordon AC, Mason AJ, Thirunavukkarasu N, Perkins GD, Cecconi M, Cepkova M, et al. Effect of early vasopressin vs norepinephrine on kidney failure in patients with septic shock: the VANISH randomized clinical trial. JAMA [Internet]. 2016 [cited 2017 May 02];316:509-18. Available from: http://jamanetwork.com/journals/jama/fullarticle/2540403

8. Andrades ME, Morina A, Spasi S, Spasojevi I. Bench-to-bedside review: sepsis-from the redox point of view. Crit Care [Internet]. 2011 [cited 2017 May 02];15(5):230. Available from: https://www.ncbi.nlm.nih.gov/pmc/articles/PMC3334726/pdf/cc10334.pdf

9. Schlottfeldt FS, Fernandes SM, Martins DM, Cordeiro P, Fonseca CD, Watanabe M, et al. Prevention of amphotericin B nephrotoxicity through use of phytotherapeutic medication. Rev Esc Enferm USP [Internet]. 2015[cited 2017 May 02];49(Spec):74-9. Available from: http://www.scielo.br/pdf/reeusp/v49nspe/1980-220X-reeusp-49-spe-0074.pdf

10. Pinto CF, Watanabe M, Vattimo MF. Hydration and N-acetylcysteine in acute renal failure caused by iodinated contrast medium: an experiment with rats. J Nephrol [Internet]. 2008[cited 2017 May 02];21(5):783-8. Available from: https://www.ncbi.nlm.nih. gov/pubmed/18949735

11. Lopes LN, Santos FAF, Oliveira LCM, Percário S, Barros CAV, Brito MVH. Copaiba oil effect on induced fecal peritonitis in rats. Acta Cir Bras[Internet]. 2015[cited 2017 May 02];30(8):568-73. Available from: http://www.scielo.br/pdf/acb/v30n8/0102-8650acb-30-08-00568.pdf

12. Dezoti Fonseca C, Watanabe M, Vattimo MF. Role of heme oxygenase-1 in polymyxin B-induced nephrotoxicity in rats. Antimicrob Agents Chemother [Internet]. 2012[cited 2017 May 02];56(10):5082-7. Available from: https://www.ncbi.nlm.nih.gov/pmc/articles/ PMC3457368/pdf/zac5082.pdf

13. Banerjee D, Madhusoodanan UK, Nayak S, Jacob J. Urinary hydrogen peroxide: a probably marker of oxidative stress in malignancy. Clin Chim Acta [Internet]. 2003[cited 2017 May 02];334(1/2):205-9. Available from: http://www.ugcfrp.ac.in/images/userfiles/48359-1.pdf

14. Erginel B, Aydin FA, Erginel T, Tanik C, Abbasoglu SD, Soysal FG, et al. Antioxidant effects of probiotics in experimentally induced peritonitis. Surg Infect[Internet]. 2016[cited 2017 May 02];17(1):114-8. Available from: http://online.liebertpub.com/doi/pdf/10.1089/ sur.2015.072

15. Doi K, Leelahavanichkul A, Yuen PS, Star RA. Animal models of sepsis and sepsis-induced kidney injury. J Clin Invest [Internet]. 2009[cited 2017 May 02];119:2868-78. Available from: https://www.ncbi.nlm.nih.gov/pmc/articles/PMC2752080/pdf/JCl39421.pdf

16. Vincent JL. The clinical challenge of sepsis identification and monitoring. PLoS Med [Internet]. 2016[cited 2017 May 02];13(5):e1002022. Available from: https://www.ncbi.nlm.nih.gov/pmc/articles/PMC4871479/pdf/pmed.1002022.pdf

17. Seely KA, Holthoff JH, Burns ST, Wang Z, Thakali KM, Gokden N, et al. Hemodynamic changes in the kidney in a pediatric rat model of sepsis-induced acute kidney injury. Am J Physiol Renal Physiol[online]. 2011[cited 2017 Jul 27];301(1):F209-17. Available from: http://ajprenal.physiology.org/content/301/1/F209.full.pdf +html

18. Kushimoto S, Gando S, Saitoh D, Mayumi T, Ogura H, Fujishima S, et al. JAAM Sepsis Registry Study Group: The impact of body temperature abnormalities on the disease severity and outcome in patients with severe sepsis: an analysis from a multicenter, prospective survey of severe sepsis. Crit Care[Internet]. 2013[cited 2017 May 02];17:R271. Available from: https://www.ncbi.nlm.nih.gov/pmc/articles/PMC4057086/ pdf/cc13106.pdf

19. Voigtsberger S, Urner M, Hasler M, Roth Z'Graggen B, Booy C, Spahn DR, et al. Modulation of early inflammatory response by different balanced and non-balanced colloids and crystalloids in a rodent model of endotoxemia. PLoS One[Internet]. 2014 [cited 2017 May 02];9(4):e93863. Available from: https://www.ncbi.nlm.nih.gov/pmc/articles/PMC3977866/pdf/pone.0093863.pdf 
20. Nakamura M, Oda S, Sadahiro T, Watanabe E, Abe R, Nakadaet T, et al. Correlation between high blood IL-6 level, hyperglycemia, and glucose control in septic patients. Crit Care[Internet]. 2012[cited 2017 May 02];16(2):R58. Available from: https://www.ncbi. nlm.nih.gov/pmc/articles/PMC3681387/pdf/cc11301.pdf

21. Coelho FUA, Watanabe M, Fonseca CD, Padilha KG, Vattimo MFF. Nursing Activities Score and Acute Kidney Injury. Rev Bras Enferm[Internet]. 2017[cited 2017 May 31];70(3):475-80. Available from: http://dx.doi.org/10.1590/0034-7167-2016-0266

22. Pinto CF, Watanabe M, Fonseca CD, Ogata Cl, Vattimo MFF. The sepsis as cause of acute kidney injury: an experimental model. Rev Esc Enferm USP[Internet]. 2012[cited 2017 May 31];46:86-90. Available from: http:/www.scielo.br/pdf/reeusp/v46nspe/en_13.pdf

23. Thiele H, Hildebrand L, Schirdewahn C, Eitel I, Adams V, Fuernau G, et al. Impact of high-dose N-acetylcysteine versus placebo on contrast-induced nephropathy and myocardial reperfusion injury in unselected patients with ST-segment elevation myocardial infarction undergoing primary percutaneous coronary intervention. The LIPSIA-N-ACC (Prospective, Single-Blind, PlaceboControlled, Randomized Leipzig Immediate PercutaneouS Coronary Intervention Acute Myocardial Infarction N-ACC) Trial. J Am Coll Cardiol[Internet]. 2010[cited 2017 Jul 27];55(20):2201-9. Available from: http://www.sciencedirect.com/science/article/pii/ S0735109710009502?via\%3Dihub

24. Rababa'h AM, Deo SV, Altarabsheh SE, De Caro J, Tarboush NA, Alzoubi KH, et al. N-Acetyl Cysteine therapy does not prevent renal failure in high-risk patients undergoing open-heart surgery. Heart Surg Forum [Internet]. 2016[cited 2017 May 31];19(1):E1622. Available from: https://www.ncbi.nlm.nih.gov/pubmed/26913679

25. Inda-Filho AJ, Caixeta A, Manggini M, Schor N. Do intravenous N-acetylcysteine and sodium bicarbonate prevent high osmolal contrast-induced acute kidney injury? a randomized controlled trial. PLoS One[Internet]. 2014[cited 2017 May 31];9(9):e107602. Available from: https://www.ncbi.nlm.nih.gov/pmc/articles/PMC4177831/pdf/pone.0107602.pdf

26. Yunos NM, Bellomo R, Hegarty C, Story D, Ho L, Bailey M. Association between a chloride-liberal vs chloride-restrictive intravenous fluid administration strategy and kidney injury in critically ill adults. JAMA[Internet]. 2012[cited 2017 Jul 27];308(15):1566-72. Available from: http://jamanetwork.com/journals/jama/fullarticle/1383234?alert=1

27. Lowes DA, Thottakam BM, Webster NR, Murphy MP, Galley HF. The mitochondria-targeted antioxidant MitoQ protects against organ damage in a lipopolysaccharide-peptidoglycan model of sepsis. Free Radic Biol Med[Internet]. 2008[cited 2017 May 31];45:1559-65. Available from: https://www.ncbi.nlm.nih.gov/pubmed/18845241

28. Vanasco V, Cimolai MC, Evelson P, Alvarez S. The oxidative stress and the mitochondrial dysfunction caused by endotoxemia are prevented by $\alpha$-lipoic acid. Free Rad Res [Internet]. 2008[cited 2017 May 31];42:815-23. Available from: http://www.tandfonline. com/doi/abs/10.1080/10715760802438709?journalCode $=$ ifra20

29. Wang W, Jittikanont S, Falk S, Li P, Feng L, Gengaro PE, et al. Interaction among nitric oxide, reaction oxygen species, and antioxidants during endotoxemia-related acute renal failure. Am J Physiol Renal Physiol[Internet]. 2003[cited 2017 May 31];284:F532-537. Available from: http://ajprenal.physiology.org/content/284/3/F532.full.pdf + html

30. Santos FN, Watanabe M, Vasco CF, Fonseca CD, Vattimo MFF. Antioxidant protection of statins in acute kidney injury induced by sepsis. Rev Esc Enferm USP[Internet]. 2014[cited 2017 May 31];48(5):818-23. Available from: http://www.scielo.br/pdf/reeusp/ v48n5/0080-6234-reeusp-48-05-820.pdf

31. Holthoff JH, Woodling KA, Doerge DR, Burns ST, Hinson JA, Mayeux PR. Resveratrol, a dietary polyphenolic phytoalexin, is a functional scavenger of peroxynitrite. Biochem Pharmacol [Internet]. 2010 [cited 2017 May 31];80:1260-5. Available from: https:// www.ncbi.nlm.nih.gov/pmc/articles/PMC2934873/pdf/nihms-216913.pdf

32. Sahu BD, Kuncha M, Sindhura GJ, Sistla R. Hesperidin attenuates cisplatin-induced acute renal injury by decreasing oxidative stress, inflammation and DNA damage. Phytomed[Internet]. 2013[cited 2017 Jul 27];20(5):453-60. Available from: http://www. sciencedirect.com/science/article/pii/S0944711312005089?via\%3Dihub\#fig0005

33. Anandan R, Subramanian P. Renal protective effect of hesperidin on gentamicin-induced acute nephrotoxicity in male Wistar albino rats. Redox Rep[Internet]. 2012 [cited 2017 Jul 27];17(5):219-26. Available from: http://www.tandfonline.com/doi/pdf/10.1179/1 351000212 Y.0000000019? needAccess $=$ true 